\title{
OCCURRENCES OF PURPLISH INDIVIDUALS OF CEPHEA CEPHEA (FORSKAL) IN THE VICINITY OF SETO
}

\author{
AUTHOR(S): \\ Tokioka, Takasi
}

CITATION:

Tokioka, Takasi. OCCURRENCES OF PURPLISH INDIVIDUALS OF CEPHEA CEPHEA

(FORSKAL) IN THE VICINITY OF SETO. PUBLICATIONS OF THE SETO MARINE BIOLOGICAL LABORATORY 1964, 12(2): 149-156

\section{ISSUE DATE:}

1964-10-15

URL:

http://hdl.handle.net/2433/175360

RIGHT: 


\title{
OCCURRENCES OF PURPLISH INDIVIDUALS OF CEPHEA CEPHEA (FORSKÅ) IN THE VICINITY OF SETO ${ }^{1)}$
}

\author{
TAKASI TOKIOKA
}

Seto Marine Biological Laboratory

With 5 Text-figures

In the autumn and the early winter last year the people of this vicinity wondered at several giant medusae which were coloured deep bright purple and drifting around the vicinity shore for days. On closer examination, they found all of them were more or less mutilated, especially heavily along the periphery. After all, however, three specimens were brought to the laboratory for identification. They were all injured heavily, except for the second specimen which was found rather in a better state of preservation. Thus, most of observations were made on that specimen, although the following descriptions were built up being supplemented by examinations on other two specimens.

\begin{tabular}{|c|c|c|c|c|c|c|}
\hline \multirow{2}{*}{ No. } & \multicolumn{3}{|c|}{ Collected } & \multicolumn{2}{|c|}{ Diameter of } & \multirow{2}{*}{ Remarks } \\
\hline & on & by & from & Umbrella & Wart-area & \\
\hline 1 & Oct. 3 & Mr. S. Imото & Tanabe Bay & $360 \mathrm{~mm}$ & $180 \mathrm{~mm}$ & Marginal lappets lost. \\
\hline 2 & Nov. 5 & Mr. T. YAMAMOTO & $\begin{array}{l}\text { Banbei-no- } \\
\text { hama Beach }\end{array}$ & 420 & 160 & $\begin{array}{l}\text { One of the two } \\
\text { specimens observed. } \\
\text { Marginal lappets } \\
\text { partially preserved. }\end{array}$ \\
\hline 3 & Dec. 3 & Mr. Musino & East Sirahamal & & 150 & Periphery torn heavily. \\
\hline
\end{tabular}

At a glance, it was found promptly that these medusae were rhizostomeans of the family Cepheidae, probably of Netrostoma or Cephea, as the central area of the exumbrella was furnished with warts of various sizes and shapes to form a prominent wart-area. The superficial examination on the subumbrella showed that there were about eight intermediate radial canals issued from the gastric cavity in each octant between paired rhopalar radial canals, and this seems to attribute the specimens to the genus Cephea. A wide range of morphological variations is shown by previous researchers on Cephea cephea

1) Contributions from the Seto Marine Biological Laboratory, No. 415.

Pubḷ. Seto Mar. Bịol. Lab., XII (2), 1964. (Article 10) 
(FORSKAL), and the morphological details of the present specimens are wholly involved in the range mentioned above. Thus, it seems to me quite doubtless that the specimens belong to Cephea cephea, a rhizostomean common in the torpical waters of the Indo-Pacific.

Now, consulting Japanese literatures on this medusa, I felt very strange at that there were no records of occurrences of purplish individuals in the Japanese wateis. Kishinouye (1902) stated, in his paper reporting for the first time the occurrence of this species in the Japanese waters under the name Perirhiza nematophora n.g. n. sp., that the medusa was coloured brown along the margin of velar lobes but otherwise quite colourless. Prof. T. UCHIDA (1936) mentions in his monographical book treating all the scyphomedusae known to Japan at that date that the periphery of umbrella is more or less brownish while other parts are colourless. The same author, then, explains in the revised edition of the Illustrated Encyclopedia of the Fauna of Japan (1947) that $C$. cephea is light brownish in colouration (p. 1606). On the other hand, it is stated in MEYER's monograph (1910) of the world scyphomedusae that Cephea cephea and its variants are colourless or blue and hyaline in general, sometimes with ocherous spots or reddish brown streaks on the bell or around warts, with a brown colouration along the margin of velar lobes, or with a chocholatebrown colouration on frilled-mouths or fairly large, reddish-brown dots on the external surface of the oral disc. And StiAsny (1938) stated that, according to Dr. ZIESEL who collected the specimens, C. cephea in the Red Sea were deep violet when they were alive. In the same paper he redescribed the recorded colourations of this medusa as fuscous-rubescent (FORSKÅ), colourless (KISHINOUYe), yellowish-rose or grayish blue (STIASNy), or violet (MENON 1930). Also he showed that specimens might be stained reddish or grayish brown when they were preserved in tin cans. Thus, the purplish colouration seems not so strange in this species in the tropical waters. Anyhow, as this is the first record of the occurrence of such purplish specimens in the Japanese waters, it seems desirable to give the descriptions of the specimens to ascertain the present indentification.

The umbrella is bright violet. The mesogloea itself is tinted light purplish, besides the endodermal walls of canals and especially of the gastric cavity are coloured much deeper and this strengthens the superficial shade on the umbrella surface. Circular and radial muscular ridges are slightly paler in colouration and they soon turn whitish in preservation in formalin. The oral disc and the oral arms are purplish at the base but brownish at the distal part on the outside, while they are pale brownish at the centro-basal but chocholate-brown at the peripheral-distal parts on the inside. The sutures are nearly whitish in the proximal half but turn to brownish distally. Frilledmouths yellowish white in the proximal half of the arms, but dark brownish 
in the distal half. Spindle-shaped protuberances are colourless and translucent. Gonads are light salmon pink.

Eight marginal lappets in each octant. The rhopalar cleft is deep, while lappets are united by webs so that the bell-margin looks nearly entire between each pair of adjoining sense organs. On the specimen No. 2, the sense organ is situated about $35 \mathrm{~mm}$ deep from the peripheral margin and the length of the lappet proper is $35.50 \mathrm{~mm}$, though the distal end of the lappet is protruded out only for $5 \mathrm{~mm}$ or so from the distal margin of the web. The wart-area is $170-180 \mathrm{~mm}$ in diameter and about $80 \mathrm{~mm}$ in height in the specimen No. 1 ; it is provided in the peripheral zone with about 30 finger-shaped protuberances up to $25 \mathrm{~mm}$ in length, while the rest is folded irregularly, partly papillated or covered with cerebriform wrinkles, leaving the central area with a $80-90 \mathrm{~mm}$ diameter rather smooth and there the texture is very thin. In the specimen No. 2, the wart-area is $140-170 \mathrm{~mm}$ in diameter. There is a narrow, cleft-like area at the centre which is smoothly surfaced and much less thickened, otherwise the surface is covered wholly with a number of protuberances which are much larger near the centre assuming rather irregularly made folds about $20 \mathrm{~mm}$ in length and sometimes finely papillated or clawshaped protuberances up to $15 \mathrm{~mm}$ in length, but become smaller and smaller toward the periphery where they are represented by spinules. In the intermediate state they assume 6-10 $\mathrm{mm}$ long oval prominences each with a spinule at the apex. The wart-area of the specimen No. 3 rather resembles that of the first specimen. It is about $150 \mathrm{~mm}$ in diameter and about $50 \mathrm{~mm}$ in height. There are about fifteen finger-shaped protuberances in the peripheral area, and the central area is somewhat thinner, though it is not defined so clearly as in other two specimens.

The oral disc attains $200 \mathrm{~mm}$ in diameter in the specimen No. 2 and this is considered to indicate that the specimen must be much larger in a perfect condition. The zone furnished with radial muscular ridges is 80 to $100 \mathrm{~mm}$ in breadth. There are about 25 main or primary radial ridges in each quatant, intervened nearly regularly by accessory radial ridges which are imperfect, lower, and confined mostly to the peripheral half of the zone. Thus, there are up to ca. 50 radial ridges in all in each quatant. The main radial muscular ridge is highest near the proximal end and attains $10-15 \mathrm{~mm}$ high there, while the accessory radial muscular ridge is higher near the peripheral end and lowered towards the proximal. The peripheral area of about $80 \mathrm{~mm}$ breadth outside the radial muscular zone is furnished with 20-25 ring muscle bundles which are interrupted on each rhopalar radial canal. Several peripheral ones of these bundles are very weakly developed and spaced rather widely so that they reach near the distal margin of lappets near the middle of each octant.

Oral arms are two-winged. It is very strange that in all the three specimens two of eight oral arms are very small and rudimentary (Text-fig. 1). 
I am not assure, but it is not impossible that overdevelopment of several of eight oral arms brings necessarily- reduction of a few arms. Main tentacles (Text-fig. 1, m.t.) situated each between each perradial pair of oral arms are stout and may attain $40-100 \mathrm{~mm}$ long and $10 \mathrm{~mm}$ thick near the base. Of other tentacles found on the oral arm, larger ones may attain $80-130 \mathrm{~mm}$ long and $5-7 \mathrm{~mm}$ thick, while smaller ones are less than $20 \mathrm{~mm}$ in length and $2 \mathrm{~mm}$ in diameter. The specimen No. 2 bears about 90 of such large tentacles, 8 to 18

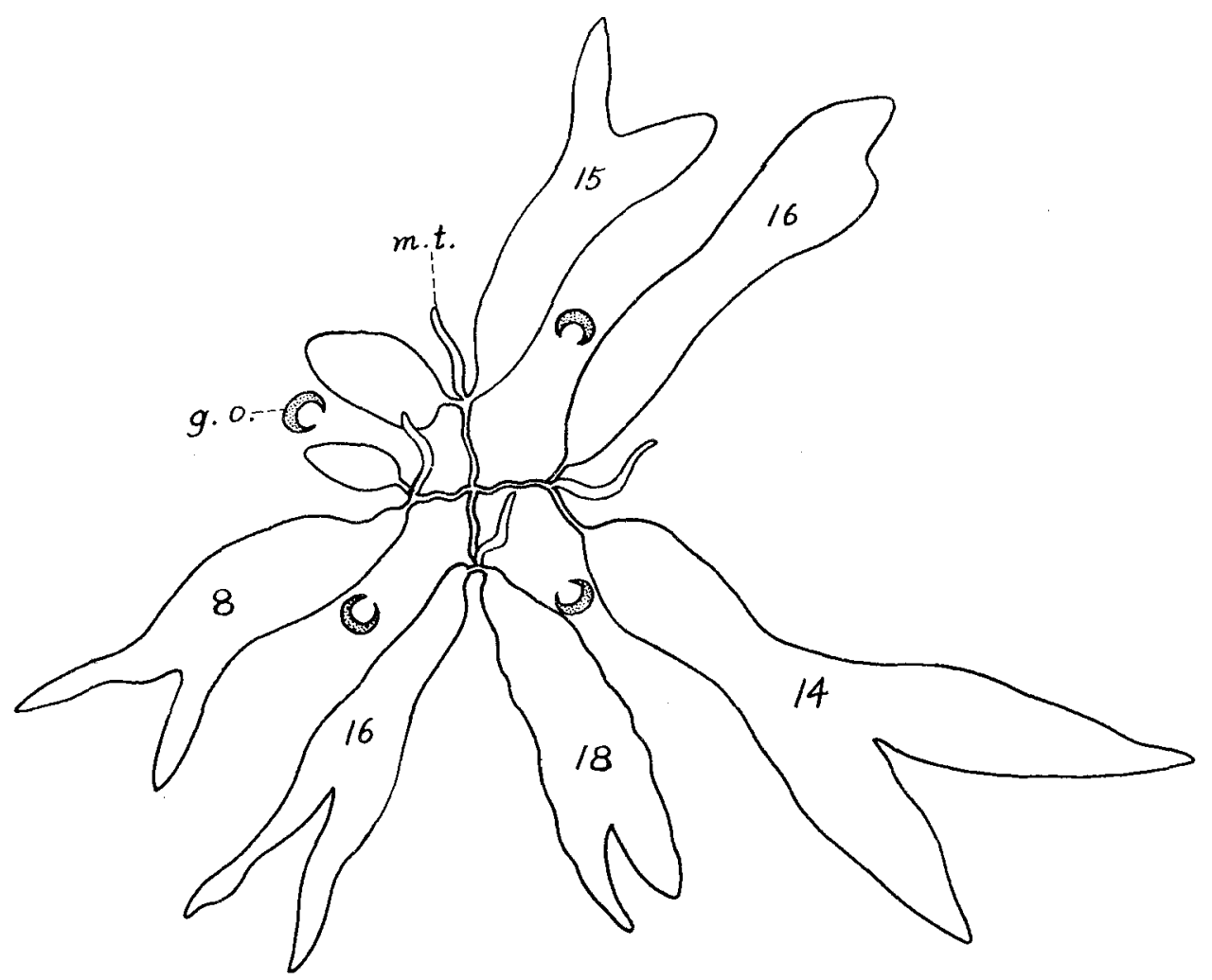

Text-fig. 1. Cephea cephea (FORSK̊̊L). Schema showing the arrangement of oral arms. g.o...subgenital ostium, m.t....main tentacle. Numerals indicate each the number of large tentacles on respective arm.

on each of six oral arms, and numerous small ones. Subgenital ostia (Textfig. $4 \mathrm{C}$ ) on the interradial axis are rather small, about $12 \mathrm{~mm}$ in long diameter, and look roughly crescent as there is a swelling along the margin on the oral side.

There are superficially about eight intermediate radial canals in each octant. It is, however, revealed by anatomical examination that there are really five canals in an octant and some of them fork immediately after they 


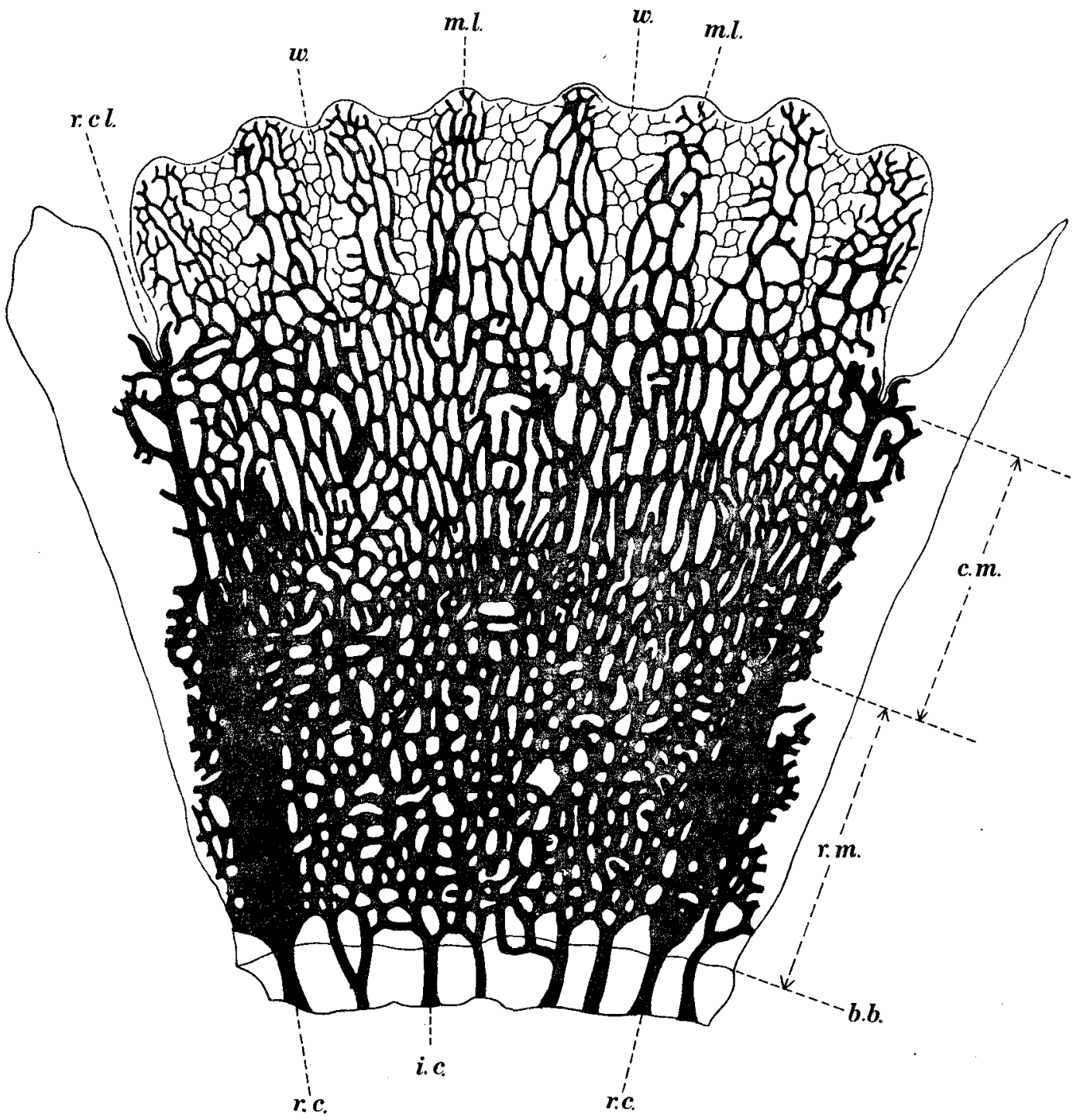

Text-fig. 2. Cephea cephea (ForSKÅ). Canal system in an octant, $\times 2 / 3$. b.b....basal border of oral disc, c.m....ring-muscle zone, i.c....intermediate radial canal, m.l...marginal lappet, r.c....rhopalar radial canal, r.cl....rhopalar cleft, r.m....radial-muscle zone, w....web.

leave the gastric cavity. Rhopalar radial canals are much thicker than others and easily distinguishable. The areolation formed by ramification of radial canals (Text-fig. 2) differs slightly in exact appearance between the radial muscular and the circular muscular zones. The canals are slightly thicker and the meshes are smaller in the former than in the latter. The canals in the web are much finer than those in the marginal lappet. Branches of canals in 
the radial muscular ridge (Text-fig. 3 ) are generally in one to three orders.

At the bottom of the rhopalar cleft, the proximal margins of the marginal lappets facing the cleft are overlapping each other and probably more or less even fused each other to make the rhopalar groove into a kind of U-shaped tube as shown in Text-fig. 5, in the upper branch of which is lying a $1 \mathrm{~mm}$ long sense-club (Text-fig. 5, s.c.). There is a shallow depression (Text-figs. 4A and $5, \mathrm{~d}$.) on the exumbrella just above the proximal end of the sense-club, and the lower aperture of the tube is bordered on the underside with a small

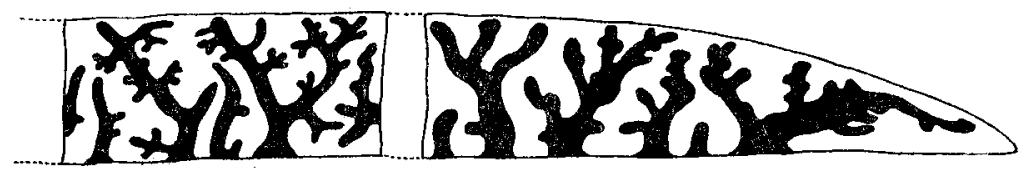

Tex-fig. 3. Cephea cephea (FORSKÅL). Canal system on radial muscular ridge.

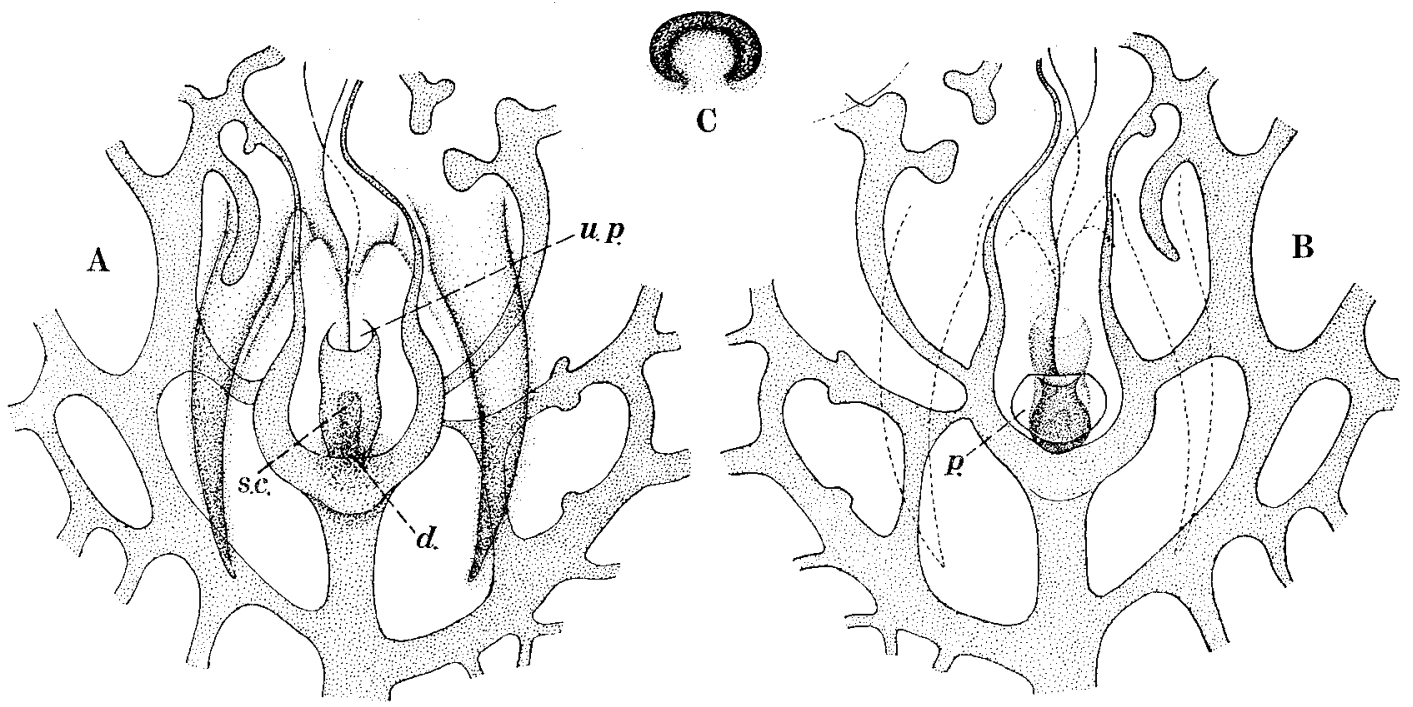

Text-fig. 4. Cephea cephea (ForskåL). A: Rhopalium, upper side. B: Rhopalium, under side. C: Subgenital ostium, $\times 1$. d....shallow depression on the exumbrella, p....pad-like swelling bordering the lower aperture, s.c....sense-club, u.p....upper aperture of rhopalar groove.

pad-like swelling (Text-figs. 4B and 5, p.). The whole rhopalar area thus formed is bordered on the exumbrella with a distinctive groove on each lateral side (Text-fig. 4A).

Genad develops in the marginal half of a pair of folded membranes on the interradial axis, which are about $80 \mathrm{~mm}$ in length and $25-35 \mathrm{~mm}$ in height. These membranes continue each to an undulating velar membrane of about $15 \mathrm{~mm}$ high stretched along the peripheral wall of the gastric cavity. 


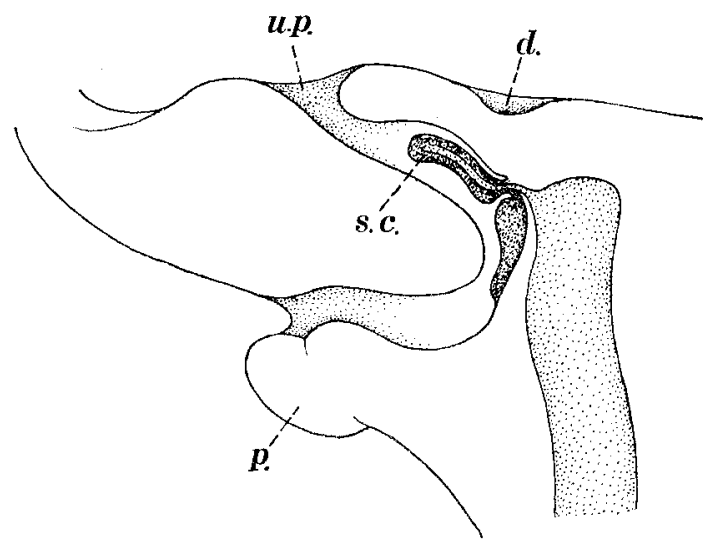

Text-fig. 5. Cephea cephea (FORSKÅL). Radial section of a rhopalium, enlarged. d....shallow depression on the exumbrella, p....pad-like swelling bordering the lower aperture, s.c...sense-club, u.p...upper aperture of rhopalar groove.

The descriptions given above seem to place the present specimens under Cephea cephea which shows so wide range of morphological variations that StIASNy (1938, p. 23) alluded to the possibility that all members of Cephea might be united into a single species. And here it must be thought of that the difference between the genera Cephea and Netrostoma lies merely in the number of intermediate radial canals in each octant, and actually the gap is recognized between five (Cephea) and three (Netrostoma). Yet really, the existence of four or five canals per octant is already reported for specimens of C. cephea from Port Denison, Queensland (STIASny 1926, p. 251). Then, what is the essential difference between Cephea and Netrostoma? If more cases showing the existence of four intermediate radial canals per octant are verified in any form of these two genera, then these must be united into a single genus Cephea.

\section{REFERENCES}

Kishinouye, K. (1902) : Some new scyphomedusae of Japan. Jour. Coll. Sci. Imp. Univ. Tokyo, Vol. 17, Fasc. 7, 17 pp., 2 pls.

MaAs, O. (1903): Die Scyphomedusen der Siboga-Expedition. Siboga-Exped., Monogr. XI, 91 pp., 12 pls.

MENoN, M. G. K. (1930): The scyphomedusae of Madras and the neighbouring coast. Bull. Madras Governm. Mus., N. Ser., Nat. Hist., Vol. III. (Through STtASNy 1938)

Meyer, A. G. (1910): The scyphomedusae. Medusae of the World, Vol. III, Carnegie Inst. Washington.

Stiasny, G. (1921): Das System der Rhizostomae. Tijdschr. d. Ned. Dierk. Vereen. (2), D1. 18, Afl. 2, pp. 93-99. 
StIAsny, G. (1922): Die Scyphomedusen-Sammlung von Dr. Th. MorTensen nebst anderen Medusen aus dem Zoologischen Museum der Universität in Kopenhagen. Vidensk. Medd, fra Dansk naturh. Foren., Bd. 73, pp. 513-538, 14 text-figs.

(1923): Gastrovascular System als Grundlage für ein neues System der Rhizostomeen. Zool. Anz., Bd. 57, Nr. 9/13, pp. 241-247, 17 text-figs.

(1926): Alte und neue Scyphomedusen von Australien. Zool. Mededeel., D1. 9, Afl. 4 , pp. $249-258,3$ text-figs.

(1929): Ueber einige Scyphomedusen aus dem Zoologischen Museum in Amsterdam. Zool. Mededeel., D1. 12, Afl. 3-4, pp. 195-216, 15 text-figs.

(1937): Ueber Netrostoma setouchianum KISHINOUYE, eine Rhizostomee von Suva (Fidschi inseln). Zool. Anz., Bd. 120, Hft. 5/6, pp. 110-115, 2 text-figs.

(1938): Die Scyphomedusen des Roten Meeres. Verhandel. d. konink. nederl. Akad.

v. Wetens. Amsterdam, Afd. Nat. (Tweede Sect.), Dl. 37, No. 2, pp. 1-35, 2 pls., 6 text-figs.

Uchida, T. (1936): Class Scyphozoa. Fauna Nipponica, Vol. III, Fasc. II, 94 pp., 48 text-figs. (in Japanese)

(1947): Scyphozoa in the Illustrated Encyclopedia of the Fauna of Japan, Revised Ed., pp. 1603-1614, 35 text-figs. (in Japanese) 